\title{
ERRATA AND CORRIGENDA
}

\section{Erratum: Proton NMR analysis of plasma is a weak predictor of coronary artery disease}

H L Kirschenlohr, J L Griffin, S C Clarke, R Rhydwen, A A Grace, P M Schofield, K M Brindle \& J C Metcalfe

Nat. Med. 12, 705-710 (2006); published online 28 May 2006; corrected after print 19 June 2006

In the version of this article initially published, the layout of the data in Tables 1 and 2 is incorrect.

The error has been corrected in the HTML and PDF versions of the article.

Erratum: Mig6 is a negative regulator of EGF receptor-mediated skin morphogenesis and tumor formation

I Ferby, M Reschke, O Kudlacek, P Knyazev, G Pantè, K Amann, W Sommergruber, N Kraut, A Ullrich, R Fässler \& R Klein

Nat. Med. 12, 568-573 (2006); published online 30 April 2006; corrected after print 16 June 2006

In the version of this article initially published, Errfil was incorrectly referred to as Erffil in several instances, and in Figure 1h the middle panels of the immunoblot were labeled Egf instead of Hgf.

The errors have been corrected in the HTML and PDF versions of the article.

\section{Corrigendum: Soluble endoglin contributes to the pathogenesis of} preeclampsia

S Venkatesha, M Toporsian, C Lam, J Hanai, T Mammoto, Y M Kim, Y Bdolah, K-H Lim, H-T Yuan, T A Libermann, I E Stillman, D Roberts, P A D'Amore, F H Epstein, F W Sellke, R Romero, V P Sukhatme, M Letarte \& S Ananth Karumanchi

Nat. Med. 12, 642-649 (2006)

Due to an editing error, some reference citations in the text are incorrect. In particular, the second citation of ref. 22 (on p. 644 ) should be ref. 23 and refs. 23-49 should be refs. 24-50.

This has been corrected in the HTML and PDF versions of the article. 